\title{
Challenges of Pancasila Ideology in the Era of Industrial Revolution 4.0: Case Study of Generation $\mathrm{Z}$ and Millennials
}

\author{
Sovi Dwi Febrian Silva', Moses Glorino Rumambo Pandin² \\ ${ }^{1}$ Faculty of Economics and Business, Airlangga University Surabaya \\ ${ }^{2}$ Faculty of Humanities, Airlangga University, Surabaya \\ Dr. Street Ir. Soekarno, Mulyorejo, Mulyorejo District, Surabaya City 60115 \\ Email: sovi.dwi.febrian-2020@,feb.unair.ac.id dan moses.glorino@fib.unair.ac.id
}

\begin{abstract}
Introduction: The imbalance between technological development and ideological strengthening has resulted in the fading of the Pancasila ideological values of millennials. Technology that accompanies everyday life seems to be the main character in human life. Yet if humans themselves do not use technology wisely, technology can be a threat to both individuals and the life of the nation and state. If technology is increasingly out of control, threats to the Pancasila ideology are very likely to occur, such as in the G 30S PKI incident. Therefore, it is necessary to take action both from the government and the community as individuals to safeguard the development of technology to be used wisely. That way, we can prevent the threat to the Pancasila ideology together. Writing this article aims to analyze how the role and influence of the Pancasila ideology on the millennial generation in the 4.0 industrial revolution and to find solutions so that the values of Pancasila remain attached to the next generation of the Indonesian nation. Method: Writing This article uses a qualitative method by using literature reviews from the results of related research journals that have been published online through websites and other online media. Results: Thirteen journals and one book have met the criteria for the inclusion of a predetermined review. Research is based on the stigma of society regarding technological developments in the Industrial revolution 4.0. Therefore, the government is expected to be more severe in implementing human capital management. Conclusion: By procuring human capital management, it will be possible that Human Resources (HR) in Indonesia will be able to carry out the ideals of a golden Indonesian generation with Pancasila values inherent in the hearts of the people and the nation's future generations.
\end{abstract}

Keywords: Pancasila, Millennial Generation, Industrial Revolution, human capital management.

\section{INTRODUCTION}

Now, who doesn't know the demographic bonus is making headlines because this can be a significant opportunity for the country's growth and people's welfare (1). However, the reality is different from the shadows and plans. The existence of this demographic bonus is not greeted with complete preparations that will directly impact the development of this country. This is viewed from the human resources who still do not meet the criteria. Generation $\mathrm{Z}$ is the dominant generation in the productive age cluster with a character by technological developments that are the basis for the 
emergence of the industrial revolution 4.0 (18). Generation $\mathrm{Z}$ has excellent potential in preparing the demographic dividend in Indonesia. However, it can also be a disaster if human capital management is not provided correctly and controlled.

In a modern era like now, everything is easy because of the development of technology. The more developing times, the more developed in the field of technology. Everyone can access the internet with the touch of a finger, regardless of whether they are old or young. So it is not strange now to see small children who always play with gadgets, because it happens because of the habit of their parents so that their children don't rebel when they get angry. In the beginning, this technology was created to make it easier for humans to live life. However, over time, many people even misuse the purpose of technology itself into doing less valuable things, which results in the person being addicted to gadgets (2).

Nowadays, we often hear the terms Industrial Revolution 4.0 and the millennial generation. The complete change of all parts of creation in the Industry through the consolidation of computerized and web innovation with traditional endeavors is the meaning of the Industrial Revolution 4.0. According to Angela Markel, digital technology and the internet are currently using intelligence in the Industrial Revolution. There are many conveniences offered by this Industrial Revolution (3). With the Intelligence of Digital Technology and the Internet, we can more freely and easily do many things, and of course, make the things we do save more energy and time.

In this era, competition in life is increasing. The existence of the Pancasila ideology is not just an ideology, because the values of Pancasila must of course still be practiced by Indonesian citizens in their lives. In addition, it is known that the formulation of Pancasila is not an easy matter. This is proven through history which states that the founders of the state went through a very, very long process in the process of formulating the Pancasila ideology. Many sacrifices have been made by the founders of the country. However, forgetting about this would be the same as disrespecting the struggles of the founders of the state at that time. In line with that, the philosophy of Pancasila should be used as a lifestyle in everyday life as an individual, both in the environment around, as a nation and as a state (4). Pancasila is referred to as a life guideline which is used as a guide or perspective in life in various fields of life (5). 
Every time you do something will be in accordance with the rules or norms in accordance with the ideology of Pancasila.

Some of the functions of the ideology itself include: 1 . science that can be used as a guide in identifying problems internationally, 2. a frame of mind in interpreting an idea and providing guidance in the goals of human behavior, 3. the rules used as a reference in attitude, 4 . as a reference and encouragement in carrying out an activity to achieve goals, 5. a view of life in identifying identity (4). a view of life for each individual in regulating attitudes in accordance with the norms in society. Based on this definition, the ideology in question is the open ideology of Pancasila. This means that it is dynamic, factual, and responsive to changing times, and has a value.

The quality contained in Pancasila is an open ideological system (6). First, the essential value is the value controlled by the country's founders, which has a static and reflective nature, not overthinking about changes according to schedule. The fundamental values of Pancasila grow from Indonesia's own identity, starting from the history of the struggle against the tormenting colonialists, as well as dreams instilled in religion and tradition. The second, instrumental value, namely the value associated with a context. Instrumental value is also a detailed description of the fundamental value. Third, practical values, especially values that are executed in everyday life, behavior, and perspective, where individuals are aware of the positive side of Pancasila. In addition to having values as an open philosophy or ideology, Pancasila also measures an available ideological system, namely dreamers, regulators, and realists. The three of them describe the content of philosophical values as a system of norms and a reflection in the lives of Indonesian citizens. These three dimensions are related to each other so that they become one unified whole.

In the era of Modern Transformation 4.0, the existence of Pancasila as the philosophy of the Indonesian nation might be minimized if the public authority as the coordinator of the state and society does not have the attention to cooperate in understanding the Pancasila decision for the interests and coexistence in the future (4). So it is believed that later the Indonesian government can provide guidelines that can reflect the values of Pancasila and the constitution in directing everything identified with the openness and advancement of science and innovation for the Indonesian nation itself. The most significant concern is the result of this approach, where all discoveries, 
improvements, and advances in science and innovation in the era of modern transformation 4.0 are needed to match the quality, nature, and standards of the Pancasila ideological system. The rapid progress of revolution 4.0 in sensor technology, data analysis, and interconnection led to the emergence of integrating all these technologies into many industrial fields.

Writing this article aims to analyze how the role and influence of the Pancasila ideology on the millennial generation in the 4.0 industrial revolution and to find solutions so that the values of Pancasila remain attached to the next generation of the Indonesian nation. This article also aims to answer several questions: what is the effect of modern upheaval 4.0 in the next millennial era in this country? How can the 4.0 industrial revolution be a positive point to support Indonesia's golden generation? How can Pancasila be relevant to the lives of the millennial generation in the midst of the development and technological growth in the industrial revolution 4.0 ?.

\section{METHODS}

The writing of this article uses the exploration method through literature reviews from 1 (one) book and 13 (thirteen) related research journals that have been published through Google Scholar. Literature research, also known as literature-based research, where data is collected through review of books, notes or journals, or diaries identified with exploration points (22). This article analyzes the influence of technological advances in modern transformation 4.0 on the millennial generation, who are the leading players who dominate the productive age in welcoming Indonesia's golden era.

Then the related Journal Search uses keywords that match the predetermined theme and title as follows:

Table 1 Keywords: Literature Review Search

\begin{tabular}{|c|c|c|c|}
\hline Pancasila & $\begin{array}{c}\text { Millennial } \\
\text { Generation }\end{array}$ & $\begin{array}{c}\text { Industrial } \\
\text { Revolution }\end{array}$ & $\begin{array}{c}\text { human capital } \\
\text { management. }\end{array}$ \\
\hline $\begin{array}{c}\text { The fading of } \\
\text { the values of } \\
\text { Pancasila }\end{array}$ & $\begin{array}{c}\text { Deviation from the } \\
\text { Pancasila ideology }\end{array}$ & Community stigma & $\begin{array}{c}\text { Losing } \\
\text { competitiveness with } \\
\text { foreign workers }\end{array}$ \\
\hline
\end{tabular}




\begin{tabular}{|c|c|c|c|}
\hline OR & OR & OR & OR \\
\hline $\begin{array}{c}\text { Less } \\
\text { implementing } \\
\text { Pancasila } \\
\text { culture }\end{array}$ & Lack of stickiness & Lack of proper use of & Not prepared to face \\
to Pancasila & technology & bonus \\
\hline
\end{tabular}

Search for articles distributed on Google Scholar, using selected slogans or keywords, in particular: Pancasila, Millennial Generation, Industrial Revolution, management human capital.

Articles or journals that fit the consideration and avoidance model are taken for additional assessment. This Writing Audit uses journals published in 2019-2021 which can be accessed in full text in pdf format and peer-reviewed journals. The journal model being reviewed is a research journal article in Indonesian with Pancasila and the Millennial Era material.

Journals that match the inclusion criteria and the 4.0 industrial revolution topic in the millennial era are then explored. The journal model was chosen to be audited as a journal in which there are topics regarding the impact of the industrial revolution 4.0 on the millennial era. The examination consideration model (inclusion) can be found in the attached table:

Table 2 Inclusion and Exclusion Criteria

\begin{tabular}{|c|c|c|}
\hline Criteria & Inclusion & Exclusion \\
\hline Population & $\begin{array}{l}\text { This research is about the } \\
\text { Pancasila ideology in the } \\
\text { Revolutionary Era } 4.0\end{array}$ & $\begin{array}{l}\text { Pancasila ideology that did not } \\
\text { affect the Industrial Revolution } \\
\text { Era } 4.0\end{array}$ \\
\hline Intervention & $\begin{array}{l}\text { Pancasila and the millennial } \\
\text { generation }\end{array}$ & $\begin{array}{l}\text { This is not Pancasila and the } \\
\text { millennial generation }\end{array}$ \\
\hline Comparator & There is no comparison & - \\
\hline Outcomes & $\begin{array}{l}\text { The influence of the industrial } \\
\text { revolution } 4.0 \text { on the } \\
\text { millennial generation }\end{array}$ & $\begin{array}{l}\text { What is not the influence of } \\
\text { the industrial revolution } 4.0 \text { on } \\
\text { the millennial generation }\end{array}$ \\
\hline $\begin{array}{l}\text { Study Design And } \\
\text { Publication Type }\end{array}$ & $\begin{array}{l}\text { Qualitative published on } \\
\text { google scholar or google }\end{array}$ & $\begin{array}{l}\text { Which are not qualitative and } \\
\text { are not published on google }\end{array}$ \\
\hline
\end{tabular}




\begin{tabular}{|l|l|l|}
\hline & scholar & scholar or google scholar. \\
\hline Publication Years & Post 2019-2021 & Pre tahun 2019 \\
\hline Languange & Indonesian & $\begin{array}{l}\text { Languages other than } \\
\text { Indonesia }\end{array}$ \\
\hline
\end{tabular}

Based on the inclusion and exclusion criteria, obtained the following results:
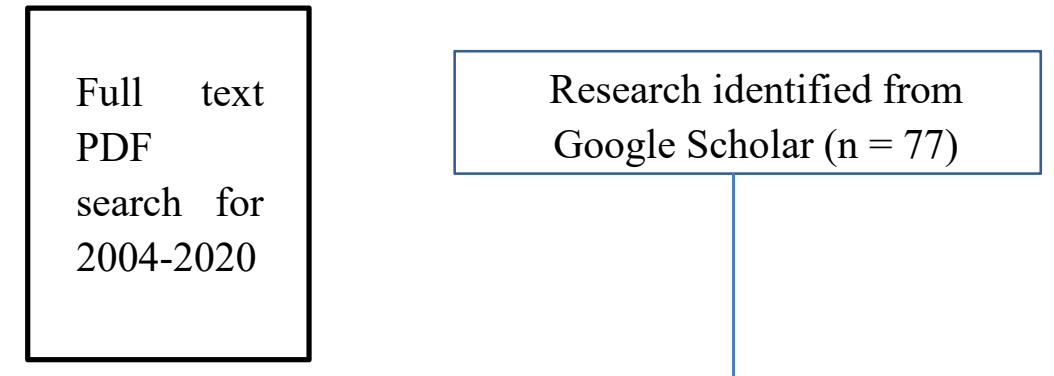

\begin{tabular}{|l|}
\hline Eligible \\
with \\
inclusion \\
criteria \\
\hline
\end{tabular}

\begin{tabular}{|l|}
\hline Eligible \\
with \\
inclusion \\
criteria \\
\hline
\end{tabular}

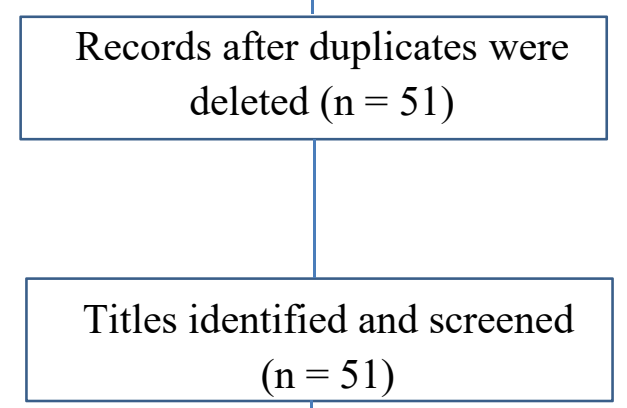

\begin{tabular}{|l|}
\hline Eligible \\
for \\
analysis \\
\end{tabular}

Abstracts were identified and filtered $(\mathrm{n}=51)$

Studies including synthesis $(\mathrm{n}=13)$ 
The analysis of this article begins by explaining the population and demographic bonus phenomena that have occurred in Indonesia. The explanation of the demographic bonus is based on the latest population data collection published by BPS in 2020 and the population growth rate. Furthermore, identification of the characteristics of the Indonesian millennial generation is carried out. After that, identification of Pancasila values and modern transformation 4.0 is carried out. After the two identifications are carried out, we will be known the relationship between the values of Pancasila and the millennial generation in the face of the 4.0 industrial revolution. From some of these identifications, it will be known how the role and influence of the Pancasila ideology on the millennial generation in the 4.0 industrial revolution and find solutions so that the values of Pancasila remain attached to the next generation of the Indonesian nation. The identification above can also answer several questions about the impact of the 4.0 industrial revolution on the nation's next millennial generation? How can the 4.0 industrial revolution be a positive point to support Indonesia's golden generation? How can Pancasila be relevant to the lives of the millennial generation in the midst of technological development and growth in the industrial revolution 4.0 ?.

The information used is preliminary information taken directly from the official statistical news (BRS) distributed by the Central Statistics Agency (BPS) as well as secondary data taken from the survey results of several related journals, which are also obtained from the Central Statistics Agency (BPS).

\section{RESULTS}

\begin{tabular}{|c|c|c|c|}
\hline $\begin{array}{c}\text { Authors and } \\
\text { Years }\end{array}$ & $\begin{array}{c}\text { Study design, } \\
\text { Sample, Variabel, } \\
\text { Instrument }\end{array}$ & Findings & Conclusion \\
\hline$(\mathrm{Fa}$ & $\begin{array}{l}\text { Design: Qualitative } \\
\text { research using } \\
\text { literature study. } \\
\text { Sample: The main } \\
\text { challenge in } \\
\text { grounding Pancasila } \\
\text { Variable: Challenges }\end{array}$ & $\begin{array}{l}\text { Socio-political } \\
\text { change, the financial } \\
\text { component that is } \\
\text { advanced through } \\
\text { transformation, can } \\
\text { cause a shift in the } \\
\text { values of Pancasila. }\end{array}$ & $\begin{array}{l}\text { In facing the } \\
\text { industrial revolution } \\
\text { 4.0, must meet many } \\
\text { challenges, but tips to } \\
\text { strengthen the } \\
\text { Pancasila ideology } \\
\text { must also be }\end{array}$ \\
\hline
\end{tabular}




\begin{tabular}{|c|c|c|c|}
\hline & $\begin{array}{l}\text { of Pancasila } \\
\text { ideology in facing } \\
\text { revolution 4.0. } \\
\text { Instrument: } \\
\text { Documentation }\end{array}$ & & supported. \\
\hline $\begin{array}{c}\text { (Lestari et al., } \\
\text { 2019) }\end{array}$ & $\begin{array}{l}\text { Design: Qualitative } \\
\text { research } \\
\text { Sample: The } \\
\text { advancement of } \\
\text { understudies in } \\
\text { establishing } \\
\text { Pancasila in the time } \\
\text { of the Modern } \\
\text { unrest. } \\
\text { Variable: } \\
\text { advancement of the } \\
\text { millennial age in } \\
\text { establishing } \\
\text { Pancasila in the } 4.0 \\
\text { time } \\
\text { Instrument: } \\
\text { Documentation }\end{array}$ & $\begin{array}{l}\text { In essence, a } \\
\text { practical realization } \\
\text { to achieve the } \\
\text { nation's goals is a } \\
\text { form of } \\
\text { implementation of } \\
\text { Pancasila in social } \\
\text { life. }\end{array}$ & $\begin{array}{l}\text { The progress of the } \\
\text { millennial generation } \\
\text { is to practice } \\
\text { Pancasila by behaving } \\
\text { and socializing well } \\
\text { in everyday life and } \\
\text { implementing it in all } \\
\text { fields. }\end{array}$ \\
\hline $\begin{array}{c}\text { (Permatasari \& } \\
\text { Hanita, 2021) }\end{array}$ & $\begin{array}{l}\text { Design: Qualitative } \\
\text { research methods } \\
\text { with CCA } \\
\text { (Conventional } \\
\text { Content Analysis) } \\
\text { analysis techniques } \\
\text { Sample: } 5 \text { millennial } \\
\text { generations. } \\
\text { Variable: Millennial } \\
\text { generation } \\
\text { Instrument: }\end{array}$ & $\begin{array}{l}\text { Pancasila with the } \\
\text { values in it can still } \\
\text { be adaptive at } \\
\text { various times. Still, } \\
\text { continuous efforts } \\
\text { are needed to } \\
\text { examine the values } \\
\text { in it so that the } \\
\text { manifestation } \\
\text { remains by the } \\
\text { context of the times }\end{array}$ & $\begin{array}{l}\text { According to the } \\
\text { views of the } \\
\text { millennial generation } \\
\text { who have been } \\
\text { interviewed, Pancasila } \\
\text { has several different } \\
\text { categories. Their } \\
\text { argument is thinking } \\
\text { that is more personal } \\
\text { and different from } \\
\text { previous generations. }\end{array}$ \\
\hline
\end{tabular}




\begin{tabular}{|c|c|c|c|}
\hline & Interview & $\begin{array}{l}\text { without changing the } \\
\text { substance of the } \\
\text { Pancasila values in } \\
\text { it. }\end{array}$ & \\
\hline $\begin{array}{c}\text { (Huwaidah, } \\
\text { 2019) }\end{array}$ & $\begin{array}{l}\text { Design: Qualitative } \\
\text { descriptive } \\
\text { Sample: A way to } \\
\text { instill the value of } \\
\text { Pancasila in the } \\
\text { millennial } \\
\text { generation. } \\
\text { Variable: } \\
\text { Embedding the value } \\
\text { of Pancasila in the } \\
\text { millennial generation } \\
\text { Instruments: } \\
\text { Documentation and } \\
\text { literature study }\end{array}$ & $\begin{array}{l}\text { Pancasila ideology } \\
\text { must be the basis of } \\
\text { our thinking in } \\
\text { acting or doing } \\
\text { something, including } \\
\text { using social media. } \\
\text { In order not to cause } \\
\text { Sara, hoaxes, pros, } \\
\text { and cons between } \\
\text { people, between } \\
\text { tribes, between } \\
\text { nations, between } \\
\text { cultures, harmony } \\
\text { does not occur. }\end{array}$ & $\begin{array}{l}\text { One way to instill the } \\
\text { Pancasila ideology in } \\
\text { the millennial } \\
\text { generation is by } \\
\text { holding a Pancasila } \\
\text { school. However, this } \\
\text { is considered less } \\
\text { effective, another } \\
\text { more effective way is } \\
\text { to create creative } \\
\text { content } \\
\text { Pancasila, considering } \\
\text { that this millennial } \\
\text { generation is solid in } \\
\text { using gadgets. }\end{array}$ \\
\hline $\begin{array}{c}\text { (Rezky et al., } \\
\text { 2019) }\end{array}$ & $\begin{array}{l}\text { Design: Qualitative } \\
\text { research } \\
\text { Sample: } 5 \text { important } \\
\text { domains in } \\
\text { developing human } \\
\text { resources } \\
\text { education } \\
\text { Variable: Millennial } \\
\text { generation readiness } \\
\text { to face the } \\
\text { revolutionary era in } \\
\text { education through } \\
\text { human resource } \\
\text { development }\end{array}$ & $\begin{array}{l}\text { As a trigger for the } \\
\text { driving industrial } \\
\text { revolution in science } \\
\text { and innovation. } \\
\text { Apart from that, } \\
\text { there are also } \\
\text { different } \\
\text { consequences such } \\
\text { as unemployment, } \\
\text { human versus } \\
\text { machine a } \\
\text { competition, and a } \\
\text { higher degree of } \\
\text { popularity in the }\end{array}$ & $\begin{array}{l}\text { Quality education and } \\
\text { training programs are } \\
\text { needed to develop } \\
\text { human resources to } \\
\text { suit public needs. }\end{array}$ \\
\hline
\end{tabular}




\begin{tabular}{|c|c|c|c|}
\hline & $\begin{array}{l}\text { Instrument: } \\
\text { Study of literature }\end{array}$ & $\begin{array}{ll}\text { demands } & \text { for } \\
\text { competence. } & \end{array}$ & \\
\hline (Persia, 2019) & $\begin{array}{l}\text { Design: Qualitative } \\
\text { Sample: } \\
\text { Characteristics of the } \\
\text { millennial generation } \\
\text { Variable: The level } \\
\text { of love of the } \\
\text { millennial generation } \\
\text { for Pancasila and } \\
\text { domestic products } \\
\text { Instrument: } \\
\text { Literature study }\end{array}$ & $\begin{array}{l}\text { Pancasila has a } \\
\text { significant part in } \\
\text { cultivating a feeling } \\
\text { of patriotism and } \\
\text { energy among } \\
\text { youngsters, whatever } \\
\text { means and exercises } \\
\text { that are done should } \\
\text { in any case be } \\
\text { founded on the good } \\
\text { side of Pancasila. }\end{array}$ & $\begin{array}{l}\text { The waning of } \\
\text { Pancasila values, the } \\
\text { spirit of nationalism, } \\
\text { and patriotism among } \\
\text { the millennial } \\
\text { generation due to the } \\
\text { influence } \\
\text { globalization, } \\
\text { therefore the role of } \\
\text { parents is significant } \\
\text { to remind the } \\
\text { importance of } \\
\text { Pancasila constantly. }\end{array}$ \\
\hline $\begin{array}{l}\text { (Paramita, } \\
\text { 2019). }\end{array}$ & $\begin{array}{l}\text { Design: Qualitative } \\
\text { research } \\
\text { Sample: Pancasila } \\
\text { values that have } \\
\text { been contained in } \\
\text { Balinese customs } \\
\text { and culture for a } \\
\text { long time } \\
\text { Variable: } \\
\text { Representation of } \\
\text { the value of } \\
\text { Pancasila in Balinese } \\
\text { culture } \\
\text { Instrument: } \\
\text { Observation }\end{array}$ & $\begin{array}{l}\text { Pancasila is the soul } \\
\text { of the state that must } \\
\text { be accepted and } \\
\text { instilled in the } \\
\text { dignity and culture } \\
\text { of the community. }\end{array}$ & $\begin{array}{l}\text { Pancasila is very } \\
\text { representative of the } \\
\text { characteristics of the } \\
\text { Indonesian nation, } \\
\text { which has a diversity } \\
\text { of ethnicities, races, } \\
\text { religions, and } \\
\text { customs. }\end{array}$ \\
\hline $\begin{array}{c}\text { (Santika et al., } \\
\text { 2019) }\end{array}$ & $\begin{array}{l}\text { Desain: Deskriptif } \\
\text { kualitatif }\end{array}$ & $\begin{array}{l}\text { The biggest threat to } \\
\text { Pancasila is cultural }\end{array}$ & $\begin{array}{l}\text { In the shock of the } \\
\text { industrial revolution, }\end{array}$ \\
\hline
\end{tabular}




\begin{tabular}{|c|c|c|c|}
\hline & $\begin{array}{l}\text { Sample: } \\
\text { Merealisasikan } \\
\text { Pergub No. } 79 \\
\text { Tahun } 2018 \text { dan } \\
\text { menjalankan isinya. } \\
\text { Variabel: } \\
\text { Memperkuat } \\
\text { Pancasila melalui } \\
\text { Peraturan } \\
\text { Instrumen: } \\
\text { dokumentasi } \\
\text { literatur. dan }\end{array}$ & $\begin{array}{l}\text { erosion. Therefore, } \\
\text { can make efforts to } \\
\text { strengthen Pancasila } \\
\text { by preserving } \\
\text { Indonesian culture. }\end{array}$ & $\begin{array}{l}\text { the effort to } \\
\text { strengthen and defend } \\
\text { Pancasila was by } \\
\text { preserving culture. } \\
\text { One of which was } \\
\text { wearing traditional } \\
\text { clothing because all } \\
\text { cultures in Indonesia } \\
\text { have the same } \\
\text { elements as Pancasila. }\end{array}$ \\
\hline $\begin{array}{c}\text { (Riadi \& Dewi, } \\
\text { 2021) }\end{array}$ & $\begin{array}{l}\text { Design: Qualitative } \\
\text { research based on } \\
\text { theories. } \\
\text { Sample: Efforts to } \\
\text { avoid conflicts with } \\
\text { the values of the } \\
\text { Pancasila ideology } \\
\text { Variable: The } \\
\text { existence and } \\
\text { strengthening of the } \\
\text { existence of the } \\
\text { values of the } \\
\text { Pancasila ideology } \\
\text { Instruments: } \\
\text { Literature study. }\end{array}$ & $\begin{array}{l}\text { In the era of modern } \\
\text { transformation } 4.0 \text {, } \\
\text { we should fight } \\
\text { against the positive } \\
\text { side of Pancasila by } \\
\text { increasing science } \\
\text { and innovation and } \\
\text { remembering the } \\
\text { world view of the } \\
\text { thinking of } \\
\text { Indonesian society. }\end{array}$ & $\begin{array}{l}\text { Perubahan yang } \\
\text { terjadi dewasa ini } \\
\text { merupakan tantangan- } \\
\text { tantangan untuk } \\
\text { Pancasila sebagai } \\
\text { ideologi. Namun, } \\
\text { inilah saat yang tepat } \\
\text { untuk Pancasila } \\
\text { menunjukkan } \\
\text { eksistensinya } \\
\text { membuktikan bahwa } \\
\text { Pancasila adalah } \\
\text { ideologi yang netral } \\
\text { dan terbuka. }\end{array}$ \\
\hline
\end{tabular}




\begin{tabular}{|c|c|c|c|}
\hline $\begin{array}{c}\text { (Hanifa \& } \\
\text { Dewi, 2021) }\end{array}$ & $\begin{array}{l}\text { Design: Qualitative } \\
\text { research } \\
\text { Sample: Students } \\
\text { who are the new } \\
\text { generation of the } \\
\text { nation's future. } \\
\text { Variable: } \\
\text { Implementation of } \\
\text { Pancasila on human } \\
\text { morals } \\
\text { Instruments: } \\
\text { Literature study }\end{array}$ & $\begin{array}{l}\text { The challenge of } \\
\text { Pancasila in modern } \\
\text { times is due to the } \\
\text { development of } \\
\text { internet technology, } \\
\text { which is increasingly } \\
\text { developing and } \\
\text { becoming more } \\
\text { sophisticated over } \\
\text { time. }\end{array}$ & $\begin{array}{l}\text { The moral is an } \\
\text { essential human } \\
\text { personality in living a } \\
\text { social life in peace } \\
\text { and harmony. But } \\
\text { human morals can be } \\
\text { influenced } \\
\text { technological } \\
\text { developments. To } \\
\text { maintain morals and } \\
\text { increase the sense of } \\
\text { nationalism, it is } \\
\text { therefore necessary to } \\
\text { apply the values of } \\
\text { Pancasila. }\end{array}$ \\
\hline $\begin{array}{l}\text { (Waruwu \& } \\
\text { Sari, 2020) }\end{array}$ & $\begin{array}{l}\text { Design: Qualitative } \\
\text { Research } \\
\text { Sample: } \\
\text { Characteristics of } \\
\text { students and create } \\
\text { opportunities for } \\
\text { character education } \\
\text { in the era } 4.0 \\
\text { Variable: Pancasila- } \\
\text { based character } \\
\text { education in the era } \\
4.0 \\
\text { Instrument: } \\
\text { Literature Study }\end{array}$ & $\begin{array}{l}\text { The values contained } \\
\text { in Pancasila are an } \\
\text { open ideology. }\end{array}$ & $\begin{array}{l}\text { Teachers play an } \\
\text { essential role in } \\
\text { learning, and to be } \\
\text { able to form student } \\
\text { character based on } \\
\text { Pancasila, teachers } \\
\text { must make the best } \\
\text { use of the } \\
\text { opportunities for } \\
\text { revolution } 4.0 \text {. }\end{array}$ \\
\hline
\end{tabular}




\begin{tabular}{|c|c|c|c|}
\hline $\begin{array}{c}\text { (Subagyo, } \\
\text { 2020). }\end{array}$ & $\begin{array}{l}\text { Design: A } \\
\text { qualitative } \\
\text { descriptive study } \\
\text { Sample: } 5 \text { universal } \\
\text { values of Pancasila } \\
\text { Variable: } \\
\text { Implementation of } \\
\text { Pancasila in warding } \\
\text { off intolerance, } \\
\text { radicalism and } \\
\text { terrorism } \\
\text { Instrument: } \\
\text { Documentation } \\
\text { study and literature } \\
\text { study. }\end{array}$ & $\begin{array}{l}\text { Pancasila in the } \\
\text { public arena ought to } \\
\text { be carried out so the } \\
\text { upsides of Pancasila } \\
\text { can get viable, } \\
\text { pertinent, } \\
\text { operational, and can } \\
\text { be effortlessly } \\
\text { perceived and drilled } \\
\text { by all parts of the } \\
\text { country, this is } \\
\text { something in is } \\
\text { imperative because } \\
\text { Pancasila should be } \\
\text { covered so it doesn't } \\
\text { seem, by all } \\
\text { accounts, to be a } \\
\text { language that is hard } \\
\text { to comprehend. In } \\
\text { this way, it is } \\
\text { essential the } \\
\text { accentuate all the } \\
\text { more with the goal } \\
\text { that the upsides of } \\
\text { Pancasila } \\
\text { executed in regular } \\
\text { daily existence. }\end{array}$ & $\begin{array}{l}\text { Pancasila is the most } \\
\text { effective medicine in } \\
\text { warding } \\
\text { intolerance, } \\
\text { radicalism aff } \\
\text { terrorism } \\
\text { implementing its } \\
\text { universal values in } \\
\text { everyday life. }\end{array}$ \\
\hline $\begin{array}{c}\text { (Nuswantari \& } \\
\text { Rachman, } \\
\text { 2020). }\end{array}$ & $\begin{array}{l}\text { Design: Literature } \\
\text { method } \\
\text { Sample: The efforts } \\
\text { and challenges of }\end{array}$ & $\begin{array}{l}\text { We should make this } \\
\text { Pancasila ideology a } \\
\text { way of life for a life } \\
\text { as an individual, be }\end{array}$ & $\begin{array}{l}\text { Problems that occur } \\
\text { in people's lives, } \\
\text { especially in the } \\
\text { nation's future }\end{array}$ \\
\hline
\end{tabular}




\begin{tabular}{|c|c|c|c|}
\hline & $\begin{array}{l}\text { Pancasila as The } \\
\text { Living Ideology in } \\
\text { an era of disruption } \\
\text { Variable: } \\
\text { Strengthening } \\
\text { Pancasila as The } \\
\text { Living Ideology } \\
\text { through the } \\
\text { revitalization of } \\
\text { Pancasila learning in } \\
\text { the era of disruption } \\
\text { Instruments: } \\
\text { Thought, } \\
\text { observation, } \\
\text { documentation. }\end{array}$ & $\begin{array}{l}\text { it in the surrounding } \\
\text { environment, nation, } \\
\text { homeland, and state. } \\
\text { The purpose of the } \\
\text { life guideline, } \\
\text { namely Pancasila, is } \\
\text { used as a guide or } \\
\text { perspective in life in } \\
\text { various fields of life, } \\
\text { be it social, political, } \\
\text { economic, and } \\
\text { others. }\end{array}$ & $\begin{array}{l}\text { generations, are } \\
\text { resolved by } \\
\text { strengthening the } \\
\text { value of Pancasila. To } \\
\text { bring Pancasila values } \\
\text { closer to them can be } \\
\text { done through } \\
\text { Pancasila learning by } \\
\text { developing and } \\
\text { technology that } \\
\text { information accompanies } \\
\text { always arrent } \\
\text { the } \\
\text { generation. }\end{array}$ \\
\hline
\end{tabular}

The total population of Indonesia, as indicated by the population data collection directed by BPS in 2020, which reached 270.20 million people, made Indonesia the fifth most populous country in the world after Brazil. The BPS publication entitled the August 2020 National Labor Force Survey Booklet published on 23 December 2020 shows data on the number of the labor force in Indonesia. The working-age population in Indonesia in 2020 is 203.97 million, divided into a workforce of 138.22 million people and a non-workforce of 65.75 million. The force itself is divided into several parts, including 9.77 million unemployed and 128.45 million people who work with a classification of 82.02 million full-time workers, 33.34 million part-time workers, and 13.09 million workers. Half unemployed. Meanwhile, not the workforce itself is divided into three parts, namely 15.35 million people are currently studying, 40.96 million people are taking care of households and 9.44 million people in other conditions (15.16).

The above phenomenon can explain that Indonesia currently has a lot of human resources. This causes the demographic bonus phenomenon to occur. But unfortunately, the Human Resources (HR) in Indonesia is presently less ready to face the demographic bonus phenomenon. We can see this from the large number of workers who are still 
unemployed because they are unable to compete with foreign workers. This demographic bonus is expected to be a distinct advantage for the Indonesian state in achieving Indonesia's golden generation ideals in 2045, which coincides with Indonesia's 100th Anniversary. Therefore, the government is expected to pay more attention to human capital management so that the generation who will realize a golden Indonesia can have readiness both in terms of social, mental, technological, and other skills. Therefore, it is essential to underline further so that the virtues of Pancasila are implemented in everyday life (17).

In realizing the golden Indonesian generation, it is also urgently needed to reinforce the Pancasila ideology to the generations who carry these ideals. Indonesian citizens must have a line of view originating from the Pancasila ideology to create a golden era in Indonesia. In socializing Pancasila, there are five main challenges, namely the mastery of Pancasila specifically, social exclusivism, which is identified with the rapid development of globalization which encourages the strengthening of the tendency to politicize personality, as well as strengthening the side effects of polarization and SARA, based social systems, social disparities, organizations. Weak Pancasila. The standardization of Pancasila values on political, monetary and social grounds is the same as the absence of the sciences in the Pancasila philosophy among heads of state, 5 . Praise Pancasila (7). These are the things that citizens and heads of state must possess in understanding the brilliant standards of the Indonesian masses. Moreover, at this time, there are more difficult challenges in which Indonesia must face the industrial revolution 4.0, which can hurt the future generations of the Indonesian nation.

By looking at the characteristics of Indonesia's young generation today, it won't be easy to win a golden Indonesian era if the central government or local governments do not immediately carry out human capital management. The younger generation who prefers foreign culture to their own country's culture is a severe problem for the Indonesian state. It is also based on a lack of excellent and equitable learning about the use of technology (20). With the younger generation being more interested in foreign cultures, the values of Pancasila will likely be eroded so that they are no longer attached to the nation's future generations. At the same time, Pancasila itself is the basis of the state and a way of life for the Indonesian state. Therefore, it is hoped that the government will quickly provide human capital management to the young generation of 
the nation's future so that they have more readiness in terms of social, technological, mental and other skills to meet the ideals of the Indonesian state to realize a golden Indonesian generation.

In implementing human capital management, the government is expected to make it happen immediately and carefully. Especially in the Industrial Revolution 4.0, technology has developed rapidly to spread that information and communication quickly. Even though the Industrial Revolution 4.0 contains many harmful elements that can cause the deterioration of cultural and Pancasila values to the younger generation, this industrial revolution is a perfect thing if used wisely. With the increasingly significant development of technology, it can quickly disseminate information and communication. This can support the improvement of the quality of Human Resources (HR) through human capital management. Due to Indonesia's geological conditions, in which each region certainly has its characteristics (19), it will be tough to carry out human capital management simultaneously offline. However, with the dissemination of information and communication, human capital management can be carried out online simultaneously.

In bringing Pancasila esteems closer to the millennial age, it very well may be done severally, to be specific, by holding Pancasila learning and giving data and instruction through online media. The degree of viability of Pancasila learning is unquestionably lower than dispersal through online media, yet with this learning, each millennial age has perceived the fundamental qualities of Pancasila. By dispersing data and correspondence online, it will be more compelling for the current generation since one of the aftereffects of innovative advances specific devices and the web can't be isolated from this age. Devices likewise have a significant impact on the chance of a decrease in the qualities of Pancasila because globalization is overgrowing through devices $(2,5)$. Accordingly, devices are considered exceptionally clear, thinking that the millennial age is consistently next to each other with these two things. With the goal that the spread and training of Pancasila are better through imaginative substance.

If Indonesia's Human Resources (HR) is good, it will be possible that this modern 4.0 transformation becomes an excellent point to realize the aspirations of a golden Indonesian generation. As the main actor in learning the golden Indonesian era, the millennial generation is obliged to take advantage of technological developments in 
the industrial revolution 4.0. The millennial generation is also obliged to embed and disseminate the values of Pancasila so that there is no deterioration which will result in the irrelevance of future generations with the goals and outlook of the Indonesian nation. Because if we look at the focus on the qualities contained in Pancasila, we can see the significance between Pancasila and events, including the modern upheaval 4.0. can see this from the historical background of Pancasila as a philosophy that is often hit by various circumstances. However, the events that have been passed through in the authentic record of the Indonesian nation are consistently negated by the Pancasila philosophy by indicating that this philosophy remains the only ideology used by the Indonesian State (21). From this affirmation, it is possible to argue that the superiority of Pancasila will be consistently related to the existence of individuals in the nation and State at all times.

\section{DISCUSSION}

From the literature above, we can conclude that the demographic level in Indonesia is very high. With that, we can understand that human resources are also very much. However, the existing human resources do not necessarily have quality based on the needs of the public, nation and state in realizing a golden Indonesia. So it is hoped that this millennial generation is a human being who has quality resources. One way to develop human resources is to impose Pancasila values on the millennial generation. Bringing Pancasila values closer to the millennial generation is indispensable. Because many of the current generations think that Pancasila is only a material to be studied and memorized, not an ideology that should also be applied in the daily life of the nation and state (7). This kind of thinking influences the morale of the nation's children and can lead to the fading of a sense of nationalism and patriotism $(6,17)$. Apart from being affected by these kinds of views and thoughts, other things that must also be faced come from developing technology and information. Technological advances are connected with the process of globalization, as we know globalization has a significant impact on changing human life (5). Pancasila itself has a vital role because by making Pancasila an ideology, people can behave and act morally. 


\section{CONCLUSION}

Human Resources (HR) in Indonesia are currently considered less ready to face the demographic bonus phenomenon. We can see this from the large number of workers who are still unemployed because they are unable to compete with foreign workers. This demographic bonus is expected to be a distinct advantage for the Indonesian state in achieving Indonesia's golden generation ideals in 2045, which coincides with Indonesia's 100th birthday. Therefore, the government is expected to pay more attention to human capital management so that the generation who will realize a golden Indonesia can have readiness both in social, mental, technological and other skills. Even though the Industrial Revolution 4.0 contains many harmful elements that can cause the deterioration of cultural and Pancasila values to the younger generation, this industrial revolution is a perfect thing if used wisely. With the increasingly significant development of technology, it can quickly disseminate information and communication. However, with the dissemination of information and communication, human capital management can be carried out online simultaneously. If Indonesia's human resources are reasonable, it will be possible that the industrial revolution 4.0 is also an excellent point to realize the ideals of a golden Indonesian generation with Pancasila inherent in the souls of the nation's future generations.

\section{REFERENCE}

1. Bayti, T. N \& Ariani, D. (2020). Millennial \& Generation Z Ideas for Golden Indonesia 2045. Belu. Fianosa Publishing (East Nusa Foundation).

2. Hanifa, S. D., \& Dewi, D. A. (2021). Implementation of Pancasila on Human Morals in the Era of the Industrial Revolution 4.0. Journal of Humanities Research, 1 (2), 17.

3. Lestari, N. I. (2020). Millennial \& Generation Z Ideas for Golden Indonesia 2045. Belu. Fianosa Publishing (East Nusa Foundation).

4. Riadi, F. S., \& Dewi, D. A. (2021). The Existence and Strengthening of the Pancasila Ideology Values in Society during the Industrial Revolution Era 4.0. Journal of Humanities Research, 1 (1), 1-7. 
5. Nuswantari, N., \& Rachman, Y. F. (2020). Strengthening Pancasila as The Living Ideology through Revitalizing Pancasila Learning in the Era of Disruption. Citizenship Journal of Pancasila and Citizenship, 8 (2), 109-119.

6. Waruwu, W. A. K., \& SARI, S. M. (2020). Strengthening Pancasila-Based Character Education for Students in the Era of the Industrial Revolution 4.0. Aquinas Scientific Journal, 3 (1), 84-95.

7. Fadilah, N. (2019). Challenges and Strengthening the Pancasila Ideology in Facing the Era of the Industrial Revolution 4.0. Journal of Digital Education, Communication, and Arts (Deca), 2 (2), 66-78.

8. Lestari, A. S., Aini, M., \& Z., A. F. (2019). The Gait of Millennial Generation in Era 4.0 in Grounding Pancasila. Attadib Journal of Elementary Education, 3 (2), 19.

9. Permatasari, O. S. D., \& Hanita, M. (2021). THE MILENIAL GENERATION PERSPECTIVE ON PANCASILA. JOURNAL OF LAW AND COMMUNITY DYNAMICS, 19 (1), 30-43.

10.Huwaidah, S. R. (2019). Pancasila School, A Powerful Way to Instill Pancasila Values in Millennial Generation.

11.Rezky, M. P., Sutarto, J., Prihatin, T., Yulianto, A., \& Haidar, I. (2019). Millennials who are ready to face the digital revolution era (Society 5.0 and the 4.0 industrial revolution) in the field of education through human resource development. Proceedings of the Postgraduate National Seminar (PROSNAMPAS), 2 (1), 11171125.

12. Persia, tresa maila ully. (2019). Being a young person besides Millennials loves Pancasila and also loves domestic products.

13. Paramita, I Gusti Agung. Representation of Pancasila Values in Balinese Culture. Vidya Wertta Volume 2 Number 2 Year 2019.

14. Santika, I. G. N., Rindawan, I. K., \& Sujana, I. G. (2019). Strengthening Pancasila through Pergub No. 79 of 2018 in Tackling Cultural Erosion in the Era of the Industrial Revolution 4.0. National Seminar on Innovation in Science, Technology and Humanities Research-InoBali, 981-990. 
15. [BPS] Central Bureau of Statistics. (2020). Official news statistics. Bps.Go.Id, 27, $1-52$.

16. Central Bureau of Statistics. (2020). Sakernas Booklet August 2020. Sakernas Booklet, 1-25.

17 Subagyo, A. (2020). Implementation of Pancasila in Warding Intolerance, Radicalism and Terrorism. Scientific Journal of Pancasila and Citizenship 6 (1), 1024.

18.Sunarto, L. R. P. (2020). Millennial \& Generation Z Ideas for Golden Indonesia 2045. Belu. Fianosa Publishing (East Nusa Foundation).

19.Arta, M. G. E. (2020). Millennial \& Generation Z Ideas for Golden Indonesia 2045. Belu. Fianosa Publishing (East Nusa Foundation).

20.Sandilla T. (2020). Millennial \& Generation Z Ideas for Golden Indonesia 2045. Belu. Fianosa Publishing (East Nusa Foundation).

21.Densi. (2020). Millennial \& Generation Z Ideas for Golden Indonesia 2045. Belu. Fianosa Publishing (East Nusa Foundation).

22.Mirzaqon A, Purwoko B. Literature Study Theoretical Basis. J UNS. 2018; 3. 